\title{
PENGEMBANGAN SMART ECONOMY KOTA PEKALONGAN MELALUI PENERAPAN E-RETRIBUSI PELAYANAN PASAR
}

\author{
Paminto Agung Christianto, Siti Nurhayati, Mujiyono, Sobrotul Imtikhanah, \\ Projo Angkasa, Shinta Dewi Rismawati, Vita Nur Latief \\ Dewan Riset Daerah Kota Pekalongan \\ Korespodensi:p_a_chr@yahoo.com
}

\begin{abstract}
ABSTRAK
Kota Pekalongan memiliki 11 titik pasar tradisional yang masing-masing pasar memiliki puluhan hingga ratusan kios dan berdasarkan data yang tercatat dalam buku "Pekalongan Dalam Angka Tahun 2016", jumlah pedagang yang ada sebanyak 4.531 pedagang. Kesulitan yang dialami oleh petugas Dinas Pasar Kota Pekalongan dalam mengelola retribusi pelayanan pasar untuk 4.531 pedagang tersebut adalah karena sistem yang digunakan masih manual yaitu dengan menggunakan karcis dan buku catatan, sehingga memungkinkan terjadinya kesalahan pencatatan atau terjadinya kecurangan dari oknum petugas atau pedagang yang tidak jujur. Kesulitan lain adalah dinas terkait sulit memantau dan mengawasi proses penarikan dan pelaporan dana retribusi pelayanan pasar, sehingga dimungkinkan penerimaan retribusi pelayanan pasar menjadi tidak optimal. Hasil kajian ini berupa rekomendasi kepada Pemerintah Kota Pekalongan dan khususnya dinas pasar kota Pekalongan untuk segera membangun dan menerapkan sistem e-retribusi pelayanan pasar di kota Pekalongan, sehingga proses penarikan dana retribusi pelayanan pasar dapat dipantau dan diawasi dengan mudah yang akhirnya akan berdampak pada optimalnya penerimaan dana retribusi pelayanan pasar yang dapat digunakan untuk mendukung penyelenggaraan pemerintahan dan pembangunan kota Pekalongan.
\end{abstract}

Kata Kunci: PAD, e-retribusi pelayanan pasar

\section{PENDAHULUAN}

Pendapatan Daerah menurut Undang-Undang Nomor 34 Tahun 2004 tentang Perimbangan Keuangan Antara Pusat dan Daerah pada Pasal 1 angka 18, yang selanjutnya disebut PAD adalah pendapatan daerah yang dipungut berdasarkan peraturan daerah sesuai dengan peraturan perundang-undangan. Sumber-sumber PAD antara lain pajak daerah, retribusi daerah, hasil pengelolaan kekayaan daerah yang dipisahkan dan lain-lain PAD yang sah (Republik Indonesia, Undang Undang Nomor 34 Tentang Perimbangan Keuangan Antara Pusat dan Daerah 2004).

Salah satu sumber PAD yang memberikan peranan penting, diperoleh dari retribusi pelayanan pasar dan di kota Pekalongan terdapat 3 (tiga) peraturan yang terkait, yaitu:

1. Peraturan Daerah kota Pekalongan No. 38 Tahun 2011 tentang Retribusi Layanan Pasar

2. Peraturan Daerah kota Pekalongan No. 4 Tahun 2012 tentang Pengelolaan dan Pemberdayaan Pasar Tradisional

3. Peraturan Walikota No. 25 Tahun 2012 tentang Tarif Retribusi Pelayanan Pasar 
Dengan peraturan tersebut, diharapkan pengelolaan dana retribusi pelayanan pasar di kota Pekalongan dapat berjalan baik dan memberikan masukan optimal ke kas daerah.

Kota Pekalongan memiliki 11 titik pasar tradisional yang masing-masing pasar memiliki puluhan hingga ratusan kios dan berdasarkan data yang tercatat dalam buku "Pekalongan Dalam Angka Tahun 2016", jumlah pedagang yang ada sebanyak 4.531 pedagang. Kesulitan yang dialami oleh petugas Dinas Pasar Kota Pekalongan dalam mengelola retribusi pelayanan pasar untuk 4.531 pedagang tersebut adalah karena sistem yang digunakan masih manual yaitu dengan menggunakan karcis dan buku catatan, sehingga memungkinkan terjadinya kesalahan pencatatan atau terjadinya kecurangan dari oknum petugas atau pedagang yang tidak jujur. Kesulitan lain adalah dinas terkait sulit memantau dan mengawasi proses penarikan dan pelaporan dana retribusi pelayanan pasar, sehingga dimungkinkan penerimaan retribusi pelayanan pasar menjadi tidak optimal.

Mencermati hal tersebut maka kebutuhan pembangunan dan penerapan eretribusi menjadi sangat penting, hal ini sejalan dengan rekomendasi dari dewan riset daerah Kota Pekalongan tentang kajian smart city (Christianto, et al. 2016). Dengan adanya e-retribusi yang sesuai dengan kebutuhan kota Pekalongan, maka kegiatan monitoring dan pengawasan pengelolaan dana retribusi pelayanan pasar dapat berjalan baik dan transparan.

\section{METODE PENGUMPULAN DATA}

Data-data yang diperlukan dalam penelitian ini, dikumpulkan dengan menggunakan beberapa metode berikut ini:

\subsection{Data Pekalongan Dalam Angka 2016}

Dari data Pekalongan dalam angka 2016, didapatkan data-data berikut ini:

1) Jumlah pasar tradisional kota Pekalongan adalah sebanyak 11 pasar tradisional, berikut nama pasarnya yang sudah diurutkan berdasarkan jumlah tempat usaha di masing-masing pasar, yaitu: Pasar Banjarsari, Pasar Grogolan, Pasar Banyurip, Pasar Sugihwaras, Pasar Kuripan, Pasar Sayun Baru, Pasar Podosugih, Pasar Anyar, Pasar Panjang Wetan, Pasar Poncol, Pasar Kraton

2) Total tempat usaha yang ada disemua pasar tradisional adalah 7.200 unit.

3) Total Pendapatan Asli Daerah (PAD) kota Pekalongan adalah Rp. 178.602.065.375 dimana dari jumlah tersebut, hasil retribusi daerah menyumbang Rp. 16.796.837.632

\subsection{Perda Kota Pekalongan No. 38 Tahun 2011}

Dari perda tentang retribusi pelayanan pasar tersebut, didapatkan data sebagai berikut:

1) Ada ketentuan khusus untuk menentukan besaran retribusi (Pasal 6)

2) Retribusi pelayanan pasar kota Pekalongan ditarik harian (Pasal 14)

3) Jika ada yang membayar terlambat atau kurang dari ketentuan maka ada denda yang dikenakannya (Pasal 18)

4) Yang masuk dalam retribusi pelayanan pasa (Pasal 1, Lampiran Perda No. 38 Tahun 2011) adalah:

a. Retribusi yang dipungut dari pedagang yang memakai toko/kios/los di area pasar Retribusi terhadap pemakaian tempat di area pasar untuk MCK

b. Retribusi terhadap pemakaian tempat sekali pakai 
c. Retribusi terhadap pemakaian tempat di area pasar untuk parkir

d. Retribusi terhadap biaya perpanjangan meminta kartu ijin penempatan tempat

e. Retribusi terhadap promosi yang dilakukan di area pasar

\subsection{Peraturan Daerah Kota Pekalongan No. 4 Tahun 2012}

Dari perda tentang pengelolaan dan pemberdayaan pasar tradisional tersebut, didapatkan data sebagai berikut:

1) Kartu Izin Pemakaian Tempat (KIPT) diberikan ke pedagang yang memanfaatkan tempat di area pasar dan lama 1 tahun, serta bisa diperpanjang (Pasal 29)

2) Pemindahan hak pemegang KIPT dikenakan biaya sebesar $200 x$ biaya retribusi pemakaian tempat (Pasal 31)

3) Sudah diamanatkan untuk melakukan pembentukan dan pengembangan sistem informasi (Pasal 39)

\subsection{Hasil kaji terap e-retribusi layanan pasar di kabupaten Kudus}

Hasil yang didapatkan adalah sebagai berikut:

1) Di Kabupaten Kudus, penerapan e-retribusi baru diterapkan pada pedagang yang memakai kios/toko/los di area pasar

2) Penarikan retribusi tidak dilakukan harian tetapi bulanan (berlaku hanya untuk pedagang yang memakai kios/toko/los)dan diperkuat dengan ketetapan dari bupati, sehingga:

- Memudahkan petugas yang mengelola dana retribusi dari pedagang

- Memperkecil adanya kecurangan dari pedagang/petugas

- Mengoptimalkan pemasukan dari retribusi pelayanan pasar

3) Pembayaran e-retribusi bekerja sama dengan pihak perbankan sehingga sistem pelaporannya bergantung dengan sistem perbankan dan dinas terkait tidak dapat sewaktu-waktu mengakses data/informasi yang diperlukan.

4) Masih dalam tahap penyempurnaan pengembangan sistem informasi untuk pengelolaan pasar

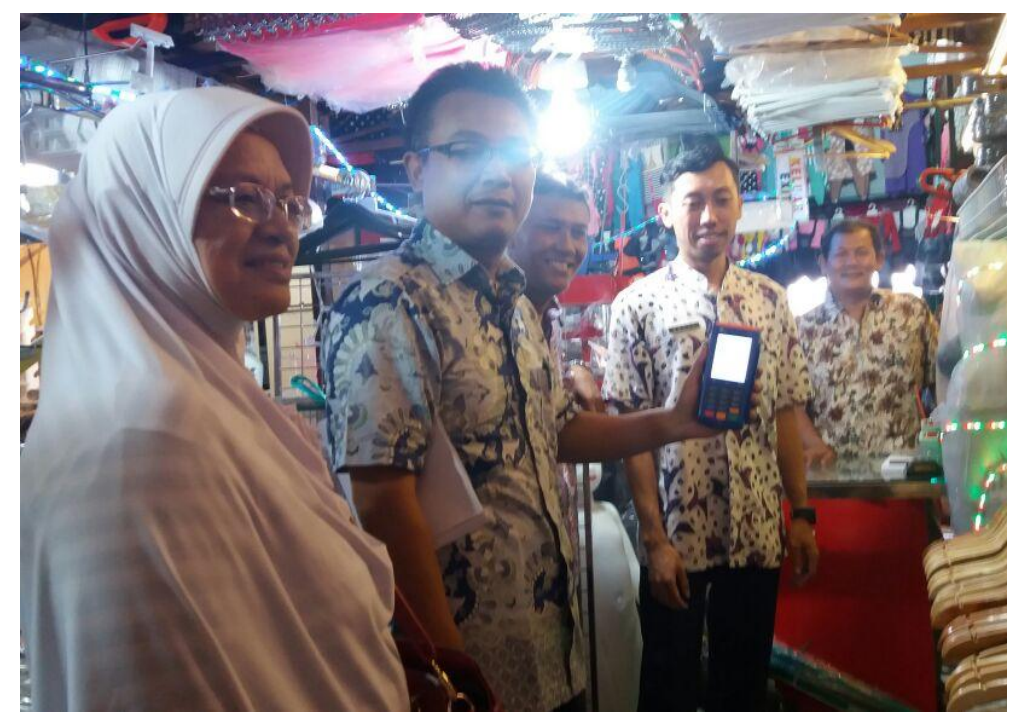

Gambar 1. Kaji Terap e-Retribusi di Pasar Kudus 


\subsection{Hasil FGD pada hari Selasa (31/10/2017)}

Berikut adalah hasil FGD:

1) Partner kerja antara dinas dengan pasar yang selama ini melalui UPTD sudah tidak ada, sehingga dinas harus mengelola sendiri 11 pasar yang ada di kota Pekalongan

2) Penarikan retribusi pasar masih dilakukan manual yaitu dengan memakai karcis dan mencatatnya ke dalam buku catatan.

3) Terjadi banyak tunggakan retribusi sehingga penarikan denda tidak dapat berjalan dengan baik, karena yang menjadi prioritas adalah pelunasan tunggakan retribusinya.

4) Biaya pengurusan KIPT adalah sebesar rp 25.000

5) Proses balik nama tidak terdeteksi dengan baik, sehingga menimbulkan potensi kehilangan pendapatan dari biaya balik nama sebesar $200 x$ biaya retribusi

6) Pendapatan retribusi pelayanan pasar dari sektor promosi masih sangat kecil karena minat pihak eksternal untuk promosi di pasar sangat kurang

7) Pengelolaan MCK di area pasar menggunakan sistem kontrak

8) Jika nanti akan dilakukan pilot project penerapan e-retribusi maka disarankan untuk diterapkan di pasar grogolan baru dengan pertimbangan pasar tersebut memiliki organisasi paguyuban pedagang pasar yang berjalan baik dan bisa menjadi mitra yang bagus.

\section{HASIL DAN PEMBAHASAN}

Berdasarkan data yang sudah dikumpulkan, maka didapatkan informasi sebagai berikut:

1) Potensi pendapatan dari retribusi pelayanan pasar di kota Pekalongan sangat besar dan diperoleh dari:

- Penerimaan retribusi dari pedagang yang menempati 7.200 pedagang

- Penerimaan denda jika ada pedagang membayar retribusi tidak sesuai ketentuan

- Penerimaan retribusi dari MCK

- Penerimaan retribusi pemakaian tempat sekali pakai

- Penerimaan retribusi parkir yang berada di area pasar

- Penerimaan biaya perpanjangan untuk memperoleh kartu ijin penempatan tempat

- Penerimaan biaya promosi di wilayah pasar

- Penerimaan dari proses pemindahan hak pemegang KIPT dikenakan biaya sebesar $200 x$ biaya retribusi pemakaian tempat

2) Namun ada beberapa kendala yang membuat penerimaan retribusi pelayanan pasar menjadi tidak optimal, yaitu:

- Dinas terkait belum memiliki sistem informasi dan proses penarikan retribusi ke pedagang masih dilakukan secara manual (pedagang diberi karcis dan dicatat dalam buku catatan)

- Banyaknya pedagang yang menunggak retribusi pelayanan pasar sehingga membuat pemberlakukan denda menjadi tidak berjalan karena prioritasnya adalah pada pelunasan tunggakan.

- Proses balik nama yang tidak dapat dideteksi dengan baik (karena belum memiliki sistem informasi), sehingga banyak kehilangan pendapatan dari biaya balik nama (200x biaya retribusi) 
- Minat pihak eksternal untuk melakukan promosi di lingkungan pasar masih kecil

- Proses permohonan kartu ijin penempatan tempat yang dilakukan pedagang tidak dapat terdeteksi dengan baik, sehingga tidak mudah mengindentifikasi pedangan yang sudah memperpanjang KIPT dan yang belum

3) Penarikan retribusi pelayanan pasar di kota Pekalongan dilakukan harian dan manual, sehingga:

- Merepotkan petugas dalam menarik retribusi dari pedagang

- Membuka celah untuk oknum pedagang/petugas yang tidak jujur

- Berdampak pada tidak optimalnya pemasukan dana retribusi pelayanan pasar ke kas daerah

4) Amanat pada Perda No. 4 tahun 2012 belum dilaksanakan, sehingga tidak mudah dinas terkait untuk melakukan monitoring dan pengawasan terhadap proses penarikan dan pengelolaan dana retribusi pelayanan pasar

\section{PENUTUP}

\subsection{Kesimpulan}

Belum adanya sistem retribusi pelayanan pasar berbasis komputer menyebabkan banyaknya kesulitan bagi dinas terkait untuk melakukan kegiatan monitoring dan pengawasan pengelolaan dana retribusi pelayanan pasar, sehingga berdampak pada tidak optimalnya pemasukan dana retribusi pelayanan pasar ke kas daerah.

\subsection{Rekomendasi}

Untuk mengoptimalkan Pendapatan Asli Daerah kota Pekalongan dari sektor retribusi pelayanan pasar maka direkomendasikan beberapa hal berikut ini:

1. Membangun dan mengembangkan sistem e-Retribusi pelayanan pasar, sehingga pemerintah kota Pekalongan (dinas terkait) dapat melakukan monitoring dan pengawasan dengan mudah-cepat-sewaktu-waktu.

2. Melakukan uji coba sistem e-Retribusi pelayanan pasar pada sebuah pasar tradisional (Pilot Project) sebelum menerapkan dalam skala yang lebih luas.

3. Mengusulkan adanya perubahan periode penarikan retribusi pedagang pasar, dari harian menjadi mingguan atau bulanan (berdasarkan pengalaman pemkab Kudus).

4. Mengembangkan Smart Economy kota Pekalongan melalui pemanfaatan "Smart Card" dan Aplikasi Pengelolaan PAD kota Pekalongan

\section{DAFTAR PUSTAKA}

Ladjamuddin B, Al-Bahra., Rekayasa Perangkat Lunak, Edisi Pertama. Yogyakarta: Graha IImu, 2006.

Pemerintah Kota Pekalongan.,Peraturan Daerah Nomor 38 Tentang Retribusi Pelayanan Pasar. Pekalongan: Pemerintah Kota Pekalongan, 2011

Pemerintah Kota Pekalongan.,Peraturan Daerah Nomor 4 Tentang Pengelolaan dan Pemberdayaan Pasar Tradisional. Pekalongan: Pemerintah Kota Pekalongan, 2012

Pemerintah Kota Pekalongan.,Peraturan Walikota Nomor 25 Tentang Tarif Retribusi Pelayanan Pasar. Pekalongan: Pemerintah Kota Pekalongan, 2012

Sinarmata, Janner., Rekayasa Perangkat Lunak. Yogyakarta: Andi, 2010. 
Republik Indonesia.,Undang Undang Nomor 34 Tentang Perimbangan Keuangan Antara Pusat dan Daerah. Jakarta: Sekretariat Negara, 2004.

Tim Kajian Dewan Reset Daerah., Kajian Tahun 2016, Kesiapan Kota Pekalongan Menuju Kota Cerdas. Pekalongan: Dewan Riset Daerah Kota Pekalongan, 2016. 